Forthcoming at Comparative Sociology

\title{
Secular Values, Economic Development, and Gender Inequality in a Global Context
}

\author{
Peyman Hekmatpour ${ }^{1}$
}

University of Oklahoma

\begin{abstract}
This article investigates how cultural and material factors can explain disparities observed in different forms of gender inequality between and within nations. Using data from multiple sources, I construct a panel dataset that includes 150 country-year observations nested in 70 countries, covering 23 years from 1991 to 2013. Through estimating hybrid panel models, this article discovers that more secular countries have lower maternal mortality ratios, higher female labor force participation rates, greater shares of parliamentary seats held by women, higher rates of women with completed secondary education, and smaller shares of the total population who adhere to inequitable gender attitudes. Moreover, from a longitudinal perspective, secularization is the only predictor of declined maternal mortality ratios and increased female parliamentary representation within a country. Interactive models suggest that further secularization within high-income nations can increase maternal mortality ratios. Furthermore, secularization's equalizing effect on parliamentary representation moderates as countries become more affluent.
\end{abstract}

Key Words: Gender Inequality, Secularization, Development, Global Stratification, Hybrid Models

\section{INTRODUCTION}

While there is a wide cross-national disparity in gender inequality in the world, there is no single country wherein complete gender equality has been attained (Evans 2017). According to recent reports, there are persistent gender gaps in economic participation and opportunity, educational attainment, health, and political empowerment, albeit to different extents, within and between countries in the world (World Economic Forum 2017). A large body of literature attributes the cross-national differences in

\footnotetext{
${ }^{1}$ peyman.hekmatpour@ou.edu
} 
gender inequality to a set of material conditions, including economic development and growth, organized women movements, collective bargaining power, and globalization (e.g., Rosenfeld and Kalleberg 1991; Dollar and Gatti 1999; Wright et al. 1995; Fontana and Wood 2000; Juhn et al. 2014; Semyonov 2018).

Nevertheless, several studies explain gender inequalities observed, within and between nations, by cultural differences in terms of the dominant religious context and citizens' shared beliefs and attitudes (e.g., Schnabel 2016a; Seguino 2011; VanHeuvelen 2014; Adams and Kirchmaier 2012; Pascall and Sung 2007; Psacharopoulos and Tzannatos 1989). Only a small number of studies, on the other hand, consider a combination of material and cultural factors as the reason for existing, and perpetuating, cross-national disparities in gender inequality (Jayachandran 2015).

In this study, I make an effort to explain the cross-national gaps in different indicators of gender inequality (i.e., maternal mortality ratios, adolescent pregnancy rates, female labor force participation, women's parliamentary representation, educational attainments, and the prevalence of inequitable gender values) using both material and cultural factors. The ultimate goal of this research is to provide empirical evidence to enable a systemic comparison between material and cultural elements responsible for increased or declined gender inequality in its different manifestations in the world.

Guided by previous studies, I try to explain gender inequality between and within nations through economic development and growth as material factors. Moreover, unlike previous studies, which use the dominant religion of a country, or percent share of the population holding inequitable gender values and beliefs, I rely on an aggregate measure that effectively captures the rise of rational and secular values in societies as a cultural element resulted from the decline in the authority of traditional social institutions such as religion, the state, and group conformity. Through this conceptualization of secular values, I test the hypothesis whether secularization (in a broader sense than 
mere irreligiousness) explains cross-national disparities in gender inequality indicators observed between and within countries.

Using data from multiple sources, I construct an unbalanced panel dataset that consists of 150 country-year observations nested in 70 countries and spans over 23 years from 1991 to 2013. I use a hybrid modeling approach capable of modeling all types of variations (i.e., within-unit and betweenunit) in panel data while enabling researchers to estimate the effects of time-varying and time-invariant factors without making unwarranted assumptions.

Overall, results suggest that culture, in terms of shared secular values, can better explain between-country variation in multiple gender inequality indicators. Countries with higher average scores of secular values have lower maternal mortality ratios, higher female labor force participation rates, greater shares of parliamentary seats held by women, higher rates of women with completed secondary education, and smaller percentages of the total population who adhere to inequitable gender attitudes. Yet, economic development is a stronger predictor, compared to secular values, of only two indicators of gender inequality: maternal mortality ratios and the percent share of the population who believe that men have more rights to a job than women.

Moreover, while economic growth only explains the decline in adolescent pregnancy rates and increased secondary educational attainment, the average of secular values is the only predictor of declined maternal mortality ratios and increased female parliamentary representation within a country. Results from additional fixed-effects models with interaction terms of secular values by economic growth suggest that further secularization within highly secular and wealthy nations can, in fact, increase maternal mortality ratios. Furthermore, there is a possibility of a ceiling effect for secularization in enhancing women's parliamentary representation status since the positive impact of secular values moderates as countries become more affluent. 
In the following sections, I will first discuss the background and theoretical framework of this study through an extensive literature review, followed by a detailed discussion of data, measures, and methods used, and a formal presentation and interpretation of the results from statistical models. Finally, I conclude with a discussion of the findings and their possible theoretical and policy implications.

\section{BACKGROUND AND THEORY}

Human culture, its altering trends, and its potential impacts on other social institutions have always been a central issue for social sciences, in general, and sociology in particular. A number of classical social thinkers (e.g., Max Weber) contended that specific elements of a given culture, such as religious values, can cause changes in material conditions of societies (Weber 1985 [1904]). Others (e.g., Karl Marx) argued that culture, as a superstructure, only reflects the infrastructure or the material conditions of a society at any given stage throughout history (Marx 1977 [1859]). Nevertheless, sociologist William Ogburn (1961 [1932]) suggested that there is a time lag in the cultural adaptation of society to the rapidly and continually altering material conditions. It is due to the phenomenon of "Cultural Lag" that we observe the continuous existence of traditional values and ideas in modern and postmodern societies (Burns 2009).

The shifts from agrarian to industrial and from industrial to post-industrial societies are always accompanied by specific changes in beliefs, values, and norms. The expansion of secular and selfexpression, as opposed to traditional and survival values, is one of the outcomes of the historical development and cultural modernization of societies. These values appear to have a significant influence on a number of social realities, including the status of women in society (Inglehart and Norris 2003). The process of industrialization brought a more significant number of women into the paid labor force, improved their educational opportunities and attainments, and gave them the chance to participate in political activities, yet it is indisputable that women still have far less power relative to men (Norris and Inglehart 2004). 
Norris and Inglehart (2004) pioneered a line of cross-national research on the association between the dominant values in societies, at different stages of development, and material conditions, including several forms of social inequality. They found significant correlations between the dominant values in a society, particularly religious values, and the level of gender equality (Norris and Inglehart 2004). According to the general theme of the secularization thesis in sociology of religion (Berger 1967; Chaves 1994; Chaves 2017; Gorski 2000; Norris and Inglehart 2004; Wallace 1966; Inglehart 1997; Bruce 2002), traditional societies are marked by higher levels of religious values, compared to modern, or more developed societies. There is evidence that religious values impact gender inequality through several possible channels and mechanisms.

Religion, in general, is associated with more traditional gender attitudes and practices (Reitz et al. 2015). At the macro level, religious institutions, for the most part, due to the phenomenon of "cultural lag," tend to reflect patriarchal values and norms rooted in traditional societies and to support the existing economic, social, and political superiority of males to females (Norris and Inglehart 2004; Sen 2007). On the other hand, at the micro level, individuals with stronger religious commitments are less likely, compared to their secular counterparts, to hold egalitarian gender attitudes (Diehl et al. 2014).

Several studies suggest that world religions do not impact gender inequality in a similar way. For instance, Psacharopoulos and Tzannatos (1989) showed female labor force participation is lower among Muslims, Hindus, and Catholics, compared to other religions, and non-religious populations. A number of scholars identify Islamic nations as the most patriarchal societies in the world. Studies suggest that women who are living in some Islamic countries, which are ruled by Sharia Law, are systematically discriminated against and are deprived of their fundamental rights, such as the right to initiate a divorce and leave the house or travel without the permission of their husbands (Baliamoune-Lutz 2007). Comparative studies show that Islamic countries, on average, are characterized by a higher literacy gap between men and women and fewer number of women in the government (Fish 2002). Research also 
shows that women in Islamic countries are suffering from property and inheritance laws that disproportionately favors men (Rossi and Rouanet 2015). Yet, to attribute all these to Islam might be somewhat inaccurate because Islam, like every other religious tradition, is subject to diverse interpretations, and historically has been (mis)used by corrupt rulers to provide justification for persistent social inequalities (Hekmatpour, Burns, and Boyd 2017; Hekmatpour 2016).

The religious composition of the population in a country can influence individuals' attitudes, and therefore results in different outcomes (VanHeuvelen 2014). For instance, the literature suggests that religious individuals who live in countries with larger populations of non-religious people tend to regress to traditional gender values and practices, mainly in order to distance themselves from the nonreligious population by drawing symbolic boundaries (Schnabel 2016b; Tranby and Zulkowski 2012). Another example is the case of East Asian countries where larger numbers of people follow Confucianism. “Strong expectations of women's obligations, without compensating rights, a hierarchy of gender and age, and a highly distinctive, vertical family structure" are some of the central ideas in Confucianism that can contribute to the perpetuation of gender inequality in several East Asian countries (Pascall and Sung 2007: 7).

Nevertheless, recent empirical findings show that the most considerable cross-national disparity in gender inequality is not between major world religions, but between religious and non-religious (i.e., secular) societies (Schnabel 2016a). Seguino (2011) studies the effect of religious values, regardless of the context, on gender inequality and finds that the higher level of religiosity is strongly associated with "inequitable gender attitudes." These attitudes include the approval of women's right to jobs, single parenthood, abortion, and divorce. She discusses that religiosity, in general, through encouraging these particular attitudes, can impact gender equality outcomes through the channels of "everyday behavior in economic transactions in labor markets, household resource allocation, and government spending" 
(Seguino 2011: 1308). Dildar (2015) also shows that higher levels of religiosity are negatively associated with female labor force participation in countries.

Religion can influence gender inequality not only by promoting patriarchal attitudes, values, and practices but also through hindering policies aimed to promote gender equality. In general, there is historical evidence that powerful religious movements, particularly in Western societies, have restricted governments' policies and efforts to reduce different types of social inequality (Jordan 2016). These policies, typically, pursue fundamental social changes and thus challenge the traditional authority of religious institutions (Htun and Weldon 2010). Consequently, religious political actors, while pursuing an agenda of preserving traditional values, tend to make efforts to influence public and political debates to repel gender promoting policies (Basedau et al. 2017; Kane 2008).

Secularization, as a theoretical concept, can refer not only to a general decline in individuals' religiosity and the authority of religious institutions (Chaves 1994) but also to a shift towards more rational values and ways of thinking as a result of modernization. According to Welzel's (2013) conceptualization, secularization refers to the rise of rational values and practice coupled with the decline in the power of divine and traditional sources of authority. Therefore, the rise of secular values, for the most part through placing less emphasis on traditional values regarding gender, and undermining the power and dominance of the traditional sources of authority (e.g., religion and the state), promote egalitarian gender norms, and can lead to a more equal society (Inglehart and Baker 2000). Previous studies show that secular values can impact different aspects of social life (Hechavarría 2016). For example, there is evidence that secularization, in a cross-national setting, is generally associated with a higher quality of life for citizens and improved scores on the human development index (Yu et al. 2017). In terms of gender inequality, another study finds that higher averages of secular values in countries is associated with a higher representation of women in directing boards of companies (Adams and Kirchmaier 2012). 
In addition to cultural elements such as secular values, material conditions of society also impact gender inequality. Traditionally, researchers have made the case that industrialization and development, followed by an increase in countries' level of affluence, result in decreased gender inequality (Collver and Langlois 1962; Semyonov 1980; Wilensky 1968; Dollar and Gatti 1999; Oppenheimer 1973; Becker and Lewis 1973). Economic growth in a country is typically accompanied by a decrease in fertility rate, and thus facilitates the incorporation of women into the labor force, which eventually reduces gender inequality (Becker and Lewis 1973; Cuberes and Teignier 2014).

On the other hand, a number of scholars argue that development in terms of technological innovations, particularly the introduction of labor-saving technologies (e.g., washing machines, vacuum cleaners, and refrigerator) also facilitated women's entrance to the formal labor market, through reducing the amount of domestic labor that women traditionally were expected to perform (Greenwood et al. 2005; Cuberes and Teignier 2014). Yet, according to other commentators, these technological innovations merely enabled middle-class women to take over the domestic tasks previously carried on by servants and, in some cases, men. For instance, the invention of stoves virtually freed men from the tiring task of fuel gathering while cooking, which was a female job, was not profoundly affected by this new technology (Cowan 2008; Shelton and John 1996; Bose, Bereano, and Malloy 1984).

Moreover, the shift from industrial to post-industrial societies increased the size of the service sector. Traditionally, women have had a comparative advantage in the service sector where there is more demand for female than for male workers (Ngai and Petrongolo 2017; Cuberes and Teignier 2014). However, recent studies show that a large service sector is typically associated with increased precarious, part-time, and flexible employment arrangements, which eventually result in greater inequality (Nicolaisen, Kavli, and Jensen 2019). Overall, previous studies in this line of research suggest that the development of modern economies, industrial growth, technological development, mass 
education, and the rise of service sector can explain differences in gender inequality observed between and within nations (Oppenheimer 1973; Semyonov 1980).

Guided by the previous findings, this paper aims to explain the observed differences in the level of gender inequality between and within nations. Gender inequality is a multifaceted theoretical concept with multiple aspects that can be explained by different factors. For example, Knight and Brinton (2017) describe the multidimensional nature of gender-role attitudes and challenge the common assumption in cross-national studies that these attitudes can be captured by a single continuum from traditional to egalitarian. Similarly, a recent study shows that despite what traditionally has been the common sense, gender attitudes have more than one dimension with the rise of a significant portion of the population who hold ambivalent attitudes towards gender equality in the public and private spheres (Scarborough, Sin, Risman 2019). Other studies suggest that gender essentialist beliefs - the idea that men and women are inherently different - has led to different outcomes and uneven gender equality in terms of social mobility, educational attainments, and labor force participation in different countries and across social classes (Charles 2011; England 2010). Therefore, in this study, I rely on a set of indicators for gender inequality rather than single-dimensional indices previously used in the literature such as the Gender Inequality Index (GII) developed by the United Nations Development Programme (UNDP), and Gender Gap Index (GPI) developed by the World Economic Forum (WEF).

The first purpose of this research is to explain disparities in gender inequality observed between and within countries by the rise of secular values as an indicator of cultural modernization. Second, I develop a systemic way to compare the relative power of cultural elements (i.e., secular values) vis-à-vis material factors, particularly the level of economic development (cross-sectional), and economic growth within a country (longitudinal). Finally, through estimating interactive models, I aim to discover the mechanisms through which secularization can (positively or negatively) impact gender inequality indicators and if these mechanisms differ by countries' income 


\section{DATA AND METHODS}

My analyses use data from multiple sources. I draw country-level data from the World Development Indicators database of the World Bank ${ }^{1}$, Penn World Table $9.0^{2}$ (Feenstra et al. 2015), and the Polity IV Project ${ }^{3}$. I also use data from the World Values Survey (WVS) ${ }^{4}$ (Inglehart et al. 2014). The final analytical sample includes 150 country-year observations nested in 70 countries, constituting an unbalanced panel where countries contribute different numbers of observations at different times to the sample. This is primarily due to the structure of data from WVS - not all countries are included in every wave of the study. Therefore, observations are only included for years in which WVS is conducted in a given country. Regarding data availability from all sources listed above, the final panel dataset for this research covers a period of 1991 to 2013. In this period, 50\% of observations are from before 2005. Overall, the distribution of observations does not show any specific trend in terms of falling in particular years.

\section{Dependent Variables}

Regarding the multidimensionality of gender inequality discussed above, I frame my analyses around multiple dependent variables, investigating the effects of secular values and economic development and growth on different societal indicators of gender inequality. Drawing on data from the World Development Indicators database, I primarily focus on gender inequality in terms of reproductive health through measuring maternal mortality ratios (i.e., the number of deaths per 100,000 live births) and adolescent pregnancy rates (i.e., the number of births per 1,000 women ages 15-19). I also consider female labor force participation (i.e. percent share of women who are active in paid labor force) as an established indicator of gender inequality in the literature, and women's political and social

\footnotetext{
${ }^{1}$ www.data.worldbank.org/products/wdi

${ }^{2}$ www.rug.nl/ggdc/productivity/pwt/

${ }^{3}$ www.systemicpeace.org/polity/polity4.htm

${ }^{4}$ www.worldvaluessurvey.org
} 
empowerment measured by parliamentary representation (i.e., the share of parliamentary seats held by women) and secondary educational attainments (i.e., the percent share of women with completed secondary education).

Moreover, in addition to these material outcomes, I also focus on the prevalence of equitable gender attitudes in populations. There are three attitudes measured by WVS with available data for all countries in the sample of this study: 1) "When jobs are scarce, men should have more right to a job than women," 2) "Men make better political leaders than women do," and 3) "University is more important for a boy than for a girl.” These attitudes are measured via 4-point Likert scales. I code this information into binary indicators distinguishing respondents who either "Strongly Agree" or "Agree" with these statements from those who "Strongly Disagree" or "Disagree." Then, I calculate the percent share of the sample who agree with these statements for each country-year unit as my dependent variables.

\section{Key Independent Variables}

The primary goal of this study is to investigate the effects of two key independent variables, secular values and economic development, on gender inequality indicators in a cross-national setting. I use the World Values Survey to draw countries' averages of secular values. Welzel (2013) constructed an index for secular values by incorporating twelve items measuring individuals' demystification of, and distancing from, traditional sources of authority, including the religion, nation, state, and group norms. I acknowledge that the label "secular values" might be confusing. However, taking a closer look at the items and sub-indices (see Table 1), one can see that this index is not merely capturing irreligiousness. Welzel (2013) uses a "compository" logic for creating this index, which states that the goal of scaling is not to make an index from items that point to a single dimension but to combine items that capture all aspects of a theoretically defined concept and make a meaningful combination that has consequences beyond each constituent item. 
The secular values index includes four sub-indices: disbelief, defiance, relativism, and skepticism, which are each measured by three items (see Table 1). The total Cronbach's alpha for these items is $0.83 .{ }^{1}$ Nevertheless, according to the "compository" logic behind its construction, "there is absolutely no requirement that the constituent parts need to be interchangeable correlates of a single dimension. In fact, to assume that the combination matters, implies that the constituent parts are, at best, moderately correlated so that their variance components are more complementary than interchangeable." (p. 61). Therefore, if we define secularization not as a mere decline in religiosity, but as a theoretical concept that refers to the rise of rational values and practices that demystify divine (e.g., religion), and quasi-divine (e.g., state, nation, and groups) sources of authority, Welzel's (2013) secular values becomes a suitable measure. Thus, we can also think of this index as a measure of cultural modernization in a broader sense, rather than only irreligiousness. Secular values index ranges from 0 (traditional) to 1 (secular). I calculate the average of secular values for each country-year by dividing the sum of the scores on the secular values index for male respondents by the size of the male sample. I focus on men in order to avoid introducing correlations with dependent variables, which might lead to biased results. $^{2}$ In the final sample of country-year units, this variable has a mean of 0.36 with a standard deviation of 0.09 .

[TABLE 1 ABOUT HERE]

\footnotetext{
${ }^{1}$ To further justify the use of the secular values index, I performed an Item Response Theory (IRT) test. Based on the principles of Confirmatory Factor Analysis (CFA), IRT is specifically developed to evaluate the quality of measures (Kean and Reilly 2014; Hekmatpour and Burns 2019; Hekmatpour 2020a, 2020b). IRT tests the quality of a measure by calculating the correlation between a predicted latent factor that loads on the observed variable, and the index created by the researcher (Harvey and Hammer 1999). Here, the correlation between the secular values index and the latent factor loading on its sub-indices is strong $(\mathrm{r}=0.954)$ and statistically significant $(\mathrm{p}<0.001)$.

${ }^{2}$ In order to check the robustness of my results regarding this coding decision, I also run my models using scores from the total sample rather than just male respondents. The overall results show no significant difference. Models using this alternative variable are available upon readers' request.
} 
Economic development is the second key independent variable in my analyses. I use the Penn World Table 9.0 to draw the real gross domestic product (GDP) at chained purchasing power parity (PPP) rates adjusted for 2011 United States dollars (Feenstra et al. 2015). I use the natural logarithm transformation of GDP per capita in my analyses to adjust for the skewness in the distribution of this variable. In the final sample, the logged GDP per capita has a mean of 2.43 with a standard deviation of $1.01 .^{1}$

\section{Control Variables}

In my analyses, I include a battery of control variables, including the size of the service sector, countries' democratic status, and trade openness as a proxy for the effect of globalization. I also control for the geographic region as a time-invariant factor. I draw the size of the service sector, as the percentage of the country's active labor force in the service sector of the economy, and trade openness measured via countries' annual trade values (in U.S. dollars) as a share of their GDP per capita, from the World Development Indicators database. I control for countries' democratic status by using the Polity IV Project democracy index, which is a continuous measure ranging from -10 (complete autocracy) to 10 (complete democracy). ${ }^{2}$

${ }^{1}$ Despite previous studies' suggestion that there might be a curvilinear relationship (i.e., a Kuznets curve) between economic development and gender inequality (Eastin and Prakash 2013), here I decide not to include a squared term of GDP per capita in my models. This decision is based on two reasons: First, one of the main goals of this study is to examine the relative power of a cultural variable (i.e., secular values) vis-à-vis material conditions, and most importantly economic development. By specifying two different relationship (one linear and one curvilinear) this comparison becomes unnecessarily more complicated. Therefore, I believe that including the squared term of GDP per capita can be counterintuitive regarding the purpose of this study. Second, results of Wald chi-square tests suggest that inclusion of a squared term for GDP per capita does not significantly increase the overall models' fit. Therefore, given my relatively small sample size, in order to avoid over fitting models, I decided not to include a squared term for GDP per capita.

${ }^{2}$ During the analyses, I tried different coding strategies for the Polity IV democracy index. I created a dummy variable distinguishing democratic countries from non-democracies, and a categorical variable which puts countries into four different groups (i.e., autocracy, closed anocracy, open anocracy, and democracy). None of these different specifications tend to introduce significant changes to the overall results. Models using these alternative coding decisions are available upon readers' request. 
The time-invariant variable for the geographic region has six categories: 1) Western Europe and North America, 2) Eastern Europe, 3) the Middle East, 4) South America, 5) East Asia, and 6) SubSaharan Africa. I take Western Europe and North America as my reference category. Table 2 shows the descriptive statistics for the variables of this study. I test for possible multicollinearity between these covariates. The average of Variance Inflation Factors (VIFs) for all independent variables is 2.56, which is below the conventional critical point of 4 . Thus, multicollinearity is not a concern in my analyses. ${ }^{1}$

\section{[TABLE 2 ABOUT HERE]}

\section{Analytical Design}

To model panel data, we can choose from a set of well-known models developed to deal with the challenges of longitudinal data structure. Conventional econometric approaches to model panel data include methods such as Between-Effects (BE), Fixed-Effects (FE), and Random-Effects (RE). While the BE approach only models the between-units variation, the FE approach only models the within-unit (country) variations. The RE approach, however, can model all the variations in the data by assuming that unit-specific errors are uncorrelated with exogenous variables and are randomly distributed. RE also assumes that both within, and between-unit variations are affecting the outcome in a same way.

The Hausman test is developed to assess the plausibility of the RE assumptions in panel datasets (Frondel and Vance 2010; Allison 2009). This test shows that the basic assumptions of the RE approach do not hold in my sample $(\chi 2=101.71, p<0.001, \mathrm{df}=7)$. Hybrid models are designed to combine the advantages of both Fixed-Effects and Random-Effects models (Allison 2009). These models can be specified as:

$$
y_{i t}=\alpha_{i}+\left(x_{i t}-\bar{x}_{i}\right) \beta_{1}+\bar{x}_{i} \beta_{2}+v_{i}+\bar{\epsilon}_{i}
$$

\footnotetext{
${ }^{1}$ During the course of analyses, I tried to control for more country-level variables, such as level of human capital, and the share of population who has access to internet, however, these variables turned out to be highly correlated with GDP per capita, thus causing multicollinearity problems.
} 
Here, $y_{i t}$, the predicted value of the outcome variable for the country $i$ at the time $t$ is a function of both between $\left(\bar{x}_{i}\right)$ and within-country $\left(x_{i t}-\bar{x}_{i}\right)$ components. This model estimates the value of the outcome variable by using between and within-unit variation simultaneously. Therefore, in order to preserve all the variation in my data, I use hybrid models to predict countries' gender inequality indicators by independent variables. However, in order to exclusively investigate what drives gender equality within a country, I also estimate Fixed-Effects models.

\section{RESULTS}

Figure 1 shows the scatter plots of gender inequality indicators by secular values. In a mere descriptive way, this figure appears to support the central hypothesis of this study - that countries with higher levels of secular values tend to have lower gender inequality. In order to move from description towards a more sophisticated explanatory analysis, in Table 3, I estimate eight hybrid models that predict gender inequality indicators by independent variables. This table reports the standardized beta coefficients, which allows for a direct comparison between effects. I have also standardized dependent variables; therefore, all interpretations should be in the form of standard deviation change in both sides of the regression equation. Hybrid models in Table 3 have three main parts: between-effects, withineffects, and the effect of time-invariant variables (i.e., geographic region). Between, within, and overall $R^{2}$ scores are reported as measures of models' fit in regard to different types of variation in the panel dataset used in this research.

\section{[FIGURE 1 ABOUT HERE]}

As we can see in the between-effects part of Table 3, the secular values index has a robust and statistically significant relationship with all dependent variables except for adolescent pregnancy rates. In other words, in a cross-sectional comparison, countries with higher average scores of secular values are shown to have lower mortality ratios, higher female labor force participation rates, higher shares of parliamentary seats held by women, higher rates of women completing secondary education, and smaller 
shares of the population who believe that men have more rights to a job than women, that men make better political leaders than women, and that university is more important for boys than for girls.

To make it more concrete, countries with secular values one standard deviation above the average of all nations tend to have maternal mortality ratios 0.195 standard deviations below the average. Similarly, one standard deviation increase in secular values is predicted to increase female labor force participation by 0.405 , parliamentary representation by 0.339 , and secondary educational attainment by 0.335 standard deviations. Moreover, countries with secular values one standard deviation above the average are predicted to have lower percentages of the population holding discriminatory gender attitudes in terms of equal rights to jobs, political leadership, and higher education, respectively, by $0.264,0.343$, and 0.297 standard deviations.

\section{[TABLE 3 ABOUT HERE]}

The level of economic development measured by GDP per capita has a significant relationship with some of the indicators of gender inequality in a cross-sectional comparison. As we can see in Table 3, one standard deviation increase in logged GDP per capita is associated with 0.456 standard deviations decrease in maternal mortality ratios, 0.507 standard deviations decrease in adolescent pregnancy rates and 0.300 standard deviation decrease in the share of the population who believe that men have more rights to a job than women do. The overall results from the between-effects part of Table 3 suggest that while economic development measured by GDP per capita is the only determinant of countries' adolescent pregnancy rates, secular values is a significant contributing factor to decreased gender inequality in terms of maternal mortality ratios, labor force participation, parliamentary representation, secondary educational attainment, and three inequitable gender attitudes.

Nevertheless, for two variables that both secular values and economic development are significant predictors, the latter has a stronger effect on gender inequality. In the case of maternal mortality ratios, for example, we can compare the slope of the regression line for GDP per capita (- 
0.456) to the one for secular values $(-0.195)$ and conclude that GDP per capita is a stronger predictor of decreased gender inequality in that front. Similarly, for Attitude 1 ("Men have more rights to a job than women"), we observe that the magnitude of the negative effect is greater for GDP per capita $(-0.300)$ relative to secular values $(-0.264)$.

These findings suggest that there is a disparity among different indicators of gender inequality in terms of their relationship with secular values and economic development. In a cross-sectional comparison, the difference in adolescent pregnancy rates is only explained by the level of economic development of a country. Moreover, secular values can adequately explain the gap between countries in terms of maternal mortality ratios, female labor force participation, women's parliamentary representation, secondary educational attainment, and inequitable gender attitudes. Nevertheless, in the case of two indicators that can be explained by both economic development and secular values (i.e., maternal mortality ratios and the share of the population who believe that men have more rights to a job than women do), the effect of economic development has a stronger magnitude.

In the within-effects part of Table 3, we see the impact of change on dependent variables, in terms of countries' deviation from their own means, on gender inequality indicators. A change in secular values significantly impacts maternal mortality ratios and female parliamentary representation. According to Table 3, one standard deviation increase in secular values within a country is associated with the decreased maternal mortality ratio in that country by 0.046 standard deviation. Similarly, one standard deviation increase in secular values within a country is shown to increase women's parliamentary representation in that country by 0.101 standard deviations. An increase in logged GDP per capita for a country - which by definition can be referred to as economic growth (if the change is positive) or decline (if the change is negative) - can significantly explain the change in adolescent pregnancy rate and women's secondary educational attainment in that country. According to Table 3, one standard deviation increase in a country's logged GDP per capita (i.e., economic growth) decreases 
the adolescent pregnancy rate by 0.059 and increases women's secondary educational attainment by 0.165 standard deviations.

As we saw in Table 3, secularization within a country is a significant driver of gender equality in terms of maternal mortality ratios and female parliamentary representation. In order to further investigate the mechanisms of change within nations, in Table 4, I estimate four fixed-effects regression models that exclusively focus on the within-unit variation in panel data. Through these fixed-effects models, I predict the change in two indicators of gender inequality (maternal mortality ratios and female parliamentary representation) by the change in secular values, GDP per capita, and other control variables. I also interact secular values with GDP per capita to see whether there is a difference in how secularization impacts gender inequality by countries' level of affluence.

\section{[TABLE 4 ABOUT HERE]}

According to Model 1 in Table 4, one standard deviation increase in secular values in a country decreases the maternal mortality ratio by 0.154 standard deviation, net of the effects of change in other variables. In Model 2, I include an interaction term of secular values by GDP per capita. Between, Within, and Overall, $R^{2}$ s reported at the bottom of Table 4 suggest that the inclusion of an interaction term substantially improves the model's goodness of fit. As we can see, the interaction term is positive and statistically significant - implying that as countries get richer (increased GDP per capita), the equalizing impact of secularization lessens. According to this model, one can argue that at some point, the negative effect of secularization on maternal mortality ratio in a country can be reversed.

This effect is illustrated in Figure 2, which shows the predicted change in maternal mortality ratios by secular values across countries' levels of affluence. As we see in this figure, secularization in low-income and middle-income countries has a negative impact on maternal mortality ratios while it has a positive effect in high-income countries. This observation is in line with previous works suggesting the possibility of an increase in some forms of gender inequality with the spread of postmaterialist values in 
highly developed nations (Charles and Bradley 2009; Cech 2013). However, this effect requires further elaborations, which I will discuss shortly.

\section{[FIGURE 2 ABOUT HERE]}

Model 3 in Table 4 shows the effects of within-country change in secular values and GDP per capita on the proportion of seats held by women in national parliaments. According to this model, one standard deviation increase in secular values within a country, net of the effects of other factors, increases female parliamentary representation by 0.334 standard deviations. In Model 4, I include an interaction term of secular values by GDP per capita to see whether the impact of secularization on female parliamentary representation differs as countries become more affluent. As we can see, the interaction term is only marginally significant, and the main effects of secular values and GDP per

capita only slightly change from Model 3 to Model 4 . The model fit statistics $\left(R^{2}\right.$ s) also suggest that the inclusion of the interaction term does not substantially improve the goodness of fit.

\section{[FIGURE 3 ABOUT HERE]}

Figure 3 shows the predicted change in female parliamentary representation by secularization across countries' income. As we see in this figure, within all countries, regardless of their income, secularization increases the proportion of seats held by women in national parliaments. Figure 3 shows that the positive slope of the regression line for secularization moderates as countries become more affluent. This change in the slope, however, is only marginally significant according to the interaction term reported in Table 4. Yet, this can suggest the possibility of a ceiling effect for increased female parliamentary representation by secularization. It appears that further secularization in already secular and affluent countries cannot have the same equalizing power as in low-income and middle-income countries. Next, I will elaborate on the results presented in this section of the article.

\section{DISCUSSION AND CONCLUSION}


In this study, I tried to explain the cross-national disparities in gender inequality indicators by a combination of cultural and material factors. There are a number of limitations to my analyses. First, the sample size of this study is small (only 150 country-year observations), which can raise concerns regarding the statistical power of regression models controlled by multiple covariates and the impact of outlier cases. Because of these issues and observed multicollinearity between GDP per capita, I could not control my analyses for the effects of other variables such as access to the internet, human development index, and the overall rates of secondary and tertiary education in the population of countries. I also could not see the impact of some theoretical variables of interest, such as the state of women's movement in a country, due to data accessibility. In order to make sure that results are not biased due to the presence of outlying cases, I repeat my analyses 150 times over each time, excluding one country-year observation. I could not find any significant change in overall results suggesting biases due to the impact of outliers.

Second, the constructed panel dataset for this study is unbalanced, which means for some countries, there is only one single observation. Therefore, the results from the within-effects part of the hybrid models and the fixed effects models can only be generalized to countries with at least two observations. In other words, my findings regarding within-country variation are only limited to those countries for which a change over time is observable in the data.

The third limitation is related to the issue of causality. While, methodologically speaking, it is impossible to draw causal inferences from observational data, panel models are considered a step forward towards establishing more causal statistical relationships. By using panel datasets, which pool observations of the same units (here countries) over time, researchers can estimate predictions that are more causal in nature compared to estimates from cross-sectional data. I should note here that estimates from panel data are not fully causal unless the researcher can reject all other possible explanations of 
change except for the estimated effect of interest (Allison 2009). It is obvious that such a task is beyond the scope of an article, such as the one at hand. Therefore, this research makes no causal claims.

Overall, the hybrid models presented in this study, acknowledging all their shortcomings and limitations, suggest that the spread of secular values and economic growth can enhance gender inequality in societies, albeit to different degrees for different gender inequality indicators, and via different mechanisms. In a cross-sectional comparison, countries with higher average scores of secular values have lower mortality ratios, higher female labor force participation rates, higher shares of parliamentary seats held by women, higher rates of women completing secondary education, and smaller shares of the population who show inequitable gender attitudes. This observation is consistent with prior studies in this line of research (Schnabel 2016a; Seguino 2011; VanHeuvelen 2014; Adams and Kirchmaier 2012; Pascall and Sung 2007; Psacharopoulos and Tzannatos 1989). Yet, for maternal mortality ratios and the percent share of the population who believe that men have more rights to a job than women, models show that economic development is a stronger predictor compared to secular values.

In a longitudinal comparison, however, hybrid models show that while economic growth only explains the decline in adolescent pregnancy rates and increased secondary educational attainments, secularization is the only predictor of declined maternal mortality ratios and increased female parliamentary representation within a country. I estimated Fixed-Effects models to focus on mechanisms through which gender inequality changes by secularization within countries. These supplementary fixedeffects models, which include interaction terms of secular values by economic growth, reveals that further secularization within highly secular and wealthy nations will, unexpectedly, increase maternal mortality ratios. This observation requires more theoretical elaborations.

In recent decades, there is evidence that a "counter-revolution" is happening in high-income and highly secular countries, wherein populist right-wing and conservative political parties are taking power 
and repealing gender promoting policies (Ignazi 1992; Oesch 2008; Lange et al. 2016; Rydgren 2005). Similarly, as I discussed above, there is evidence that powerful religious movements, sometimes coupled with nationalist ideologies, can hinder governments' policies designed to reduce different types of social inequality in Western societies (Davis 2019; Jordan 2016). There is a number of studies suggesting that these religious movements are on the rise in some of the most secular places of the world and as a reaction to the process of secularization (Tranby and Zulkowski 2012; Emerson and Hartman 2006).

Moreover, previous studies suggest that legalization and the provision of safe abortion are among the crucial factors predicting declined maternal mortality in all countries in the world (Okonofua 2008; Latt, Milner, and Kavanagh 2019; Singh and Ratnam 1998; Ganatra and Faundes 2016). On the other hand, criminalization of abortion, as one of the central tenets of the uprising neoconservative political movements, in the United States and other western countries, is among one of the contributing factors to the stalled decline, or in some countries, a rise in maternal mortality ratios (Shaw and Norman 2018; Kelly et al. 2017; Millar 2016; Faúndes and Shah 2015). The uprising of the anti-abortion activism in terms of rallies and online campaigns in Europe shows that abortion is not yet a closed case, even in highly secular societies (De Zordo, Mishtal, and Anton 2016). Therefore, increased numbers of abortion-related deaths, and thus the overall maternal mortality ratio, can be considered as a result of neoconservative political parties gaining power in secular societies. Thus, the increase of maternal mortality ratios observed in longitudinal models of this study can be explained in part by further secularization in high-income societies, which, according to previous studies, is associated with the rise of anti-secular movements as a reaction from more religious and conservative segments of the population (Schnabel 2016b; Tranby and Zulkowski 2012).

Female parliamentary representation, as one of the indicators of macro-level gender inequality, increases as countries become more secular. However, this association is also mediated by economic growth. Fixed-effects models suggest that secularization in low-income countries have a stronger 
equalizing power in terms of increasing the proportion of seats held by women in national parliaments. Yet, this effect becomes weaker as countries grow economically. In other words, cultural secularization in high-income nations does not increase the number of females in parliaments as much as it does in low-income countries in the world.

Theoretically, both interactions examined in this article show the possibility of a macro-level "glass ceiling" in different forms of gender equality. Economic growth and secularization tend to have a mutually enforcing equalizing effect on various manifestations of gender equality. However, in highincome post-industrial societies, increased secularization, through evoking anti-secular and conservative movements, can mitigate the equalizing processes leading to hindered decline or even an increase in some of the indicators of gender inequality. Thus, if the secularization thesis - that modernization, particularly in terms of economic development and growth, always promotes secularization (Chaves 1994; Chaves 2017; Gorski 2000; Norris and Inglehart 2004; Wallace 1966; Inglehart 1997; Bruce 2002) - is true, then one can hypothesize that gender inequality, in its multiple facets, while can be reduced, cannot be eliminated at least in the foreseeable future.

Policymakers concerned about gender inequality, especially in culturally traditional societies, can benefit from findings presented in this paper as a continuation of prior studies in this line of research. The relationship between economic growth and gender inequalities is reciprocal. There is a large body of literature showing how different forms of gender inequality can hinder economic development (e.g., Barro and Lee 1993; Barro and Lee 1996; Dollar and Gatti 1999; Klasen 2002; Forbes 2000; Knowles et al. 2002; Yamarik and Ghosh 2003; Barro and Sala-i-Martin 2003; AbuGhaida and Klasen 2004). Therefore, from a sheer economic perspective, it is rational for countries to invest in gender equalizing programs and policies, even when their only intention is to preserve a country's economic growth. Social activists, particularly in more affluent and developed countries, can also benefit from the results of this study. Advocating for gender equality should be accompanied by a 
regard for the fact that the spread of secular values, to its highest degree, can cause a reaction from more religious segments of the population, which in the long-term, can counteract gender promoting efforts and policies. 


\section{REFERENCES}

Abu-Ghaida, Dina, and Stephan Klasen. 2004. "The costs of missing the Millennium Development Goal on gender equity." World Development 32(7): 1075-1107.

Adams, Renee and Kirchmaier, Tom. 2012. "Making It to the Top: From Female Labor Force Participation to Boardroom Gender Diversity." SSRN Electronic Journal. Available SSRN: https://ssrn.com/abstract=2192918

Allison, Paul David. 2009. Fixed Effects Regression Models. London: SAGE.

Baliamoune-Lutz, M. 2007. "Globalisation and gender inequality: Is Africa different?" Journal of African Economies 16(2): 301-348.

Barro, Robert J., and Jong-Wha Lee. 1993. "International comparisons of educational attainment." Journal of monetary economics 32(3): 363-394.

Barro, Robert J., and Jong Wha Lee. 1996. "International measures of schooling years and schooling quality." The American Economic Review 86(2): 218-223.

Barro, Robert J., and X. Sala-i-Martin. 2003. Economic Growth. Cambridge: MIT Press.

Becker, Gary S., and H. Gregg Lewis. 1973. "On the Interaction between the Quantity and Quality of Children." Journal of political Economy 81(2): 279-288.

Berger, Peter L. 1967. The Sacred Canopy; Elements of a Sociological Theory of Religion. Garden City, NY: Doubleday.

Bose, Christine E., Philip L. Bereano, and Mary Malloy. 1984. "Household technology and the social construction of housework." Technology and Culture 25(1): 53-82.

Bruce, Steve. 2002. God is Dead: Secularization in the West. Oxford: Blackwell.

Cech, Erin A. 2013. "The self-expressive edge of occupational sex segregation." American Journal of Sociology 119(3): 747-789.

Charles, Maria. 2011. "A world of difference: international trends in women's economic status." Annual Review of Sociology 37: 355-371.

Charles, Maria, and Karen Bradley. 2009. "Indulging our gendered selves? Sex segregation by field of study in 44 countries." American journal of sociology 114(4): 924-976.

Chaves, Mark. 1994. "Secularization as declining religious authority." Social Forces 72(3): 749-774.

Chaves, Mark. 2017. American Religion: Contemporary Trends. Princeton: Princeton University Press.

Collver, Andrew, and Eleanor Langlois. 1962. "The Female Labor Force in Metropolitan Areas: An International Comparison.” Economic Development and Cultural Change 10(4): 367-385.

Cowan, Ruth Schwartz. 2008. More Work for Mother: the Ironies of Household Technology from the Open Hearth to the Microwave. New York, NY: Basic Books.

Cuberes, David, and Marc Teignier. 2014. "Gender inequality and economic growth: A critical review." Journal of International Development 26(2): 260-276.

Davis, Joshua T. 2019. "Funding God's policies, defending whiteness: Christian nationalism and whites' attitudes towards racially-coded government spending." Ethnic and Racial Studies 42(12): 21232142.

De Zordo, Silvia, Joanna Mishtal, and Lorena Anton, (eds.). 2016. A fragmented landscape: Abortion governance and protest logics in Europe. New York: Berghahn Books.

Diehl, Claudia, Matthias Koenig, and Kerstin Ruckdeschel. 2014. "Religiosity and gender equality: comparing natives and Muslim migrants in Germany." In Bulmer, Martin and John Solomos (eds.). Gender, Race and Religion: Intersections and Challenges. London: Routledge, Taylor and Francis Group.

Dollar, David, and Roberta Gatti. 1999. Gender inequality, income, and growth: are good times good for women?. Washington, DC: Development Research Group, The World Bank, 1999. 
Eastin, Joshua, and Aseem Prakash. 2013. "Economic development and gender equality: Is there a gender Kuznets curve?." World Politics 65(1): 156-186.

Emerson, Michael O., and David Hartman. 2006. "The rise of religious fundamentalism.” Annual Review of Sociology 32: 127-144.

England, Paula. 2010. “The gender revolution: Uneven and stalled.” Gender \& society 24(2): 149-166.

Evans, Mary. 2017. The Persistence of Gender Inequality. Cambridge, UK: Polity Press.

Faúndes, Anibal, and Iqbal H. Shah. 2015. "Evidence supporting broader access to safe legal abortion." International Journal of Gynecology \& Obstetrics 131: 56-59.

Feenstra, Robert C., Robert Inklaar and Marcel P. Timmer. 2015. "The Next Generation of the Penn World Table" American Economic Review 105(10): 3150-3182.

Fish, M. Steven. 2002. "Islam and authoritarianism." World politics 55(1): 4-37.

Fontana, Marzia, and Adrian Wood. 2000. "Modeling the Effects of Trade on Women, at Work and at Home." World development 28(7): 1173-1190.

Forbes, Kristin J. 2000. "A reassessment of the relationship between inequality and growth." American economic review 90(4): 869-887.

Frondel, Manuel, and Colin Vance. 2010. "Fixed, random, or something in between? A variant of Hausman's specification test for panel data estimators." Economics Letters 107(3): 327-329.

Ganatra, Bela, and Anibal Faundes. 2016. "Role of birth spacing, family planning services, safe abortion services and post-abortion care in reducing maternal mortality." Best Practice \& Research Clinical Obstetrics \& Gynaecology 36: 145-155.

Gorski, Philip S. 2000. "Historicizing the Secularization Debate: Church, State, and Society in Late Medieval and Early Modern Europe, ca. 1300 to 1700.” American Sociological Review 65(1): 138-167.

Greenwood, Jeremy, Ananth Seshadri, and Mehmet Yorukoglu. 2005. "Engines of liberation.” The Review of Economic Studies 72(1): 109-133.

Harvey, Robert J., and Allen L. Hammer. 1999. "Item response theory." The Counseling Psychologist 27(3): 353-383.

Hechavarría, Diana M. 2016. "The impact of culture on national prevalence rates of social and commercial entrepreneurship.” International entrepreneurship and management journal 12(4): 1025-1052.

Hekmatpour, Peyman. 2016. "Shia Islam and Religious Forbearance among students in Iran A qualitative study using the concept of social norms." International Journal of Humanities and Social Science Invention 5(12): 65-73.

Hekmatpour, Peyman. 2020a. "Inequality and Religiosity: Different Secularization Pathsfor Developed and Developing Nations.” International Journal of Sociology 50(4): 286-309.

Hekmatpour, Peyman. 2020b. "Right-Wing Stewards: The Promoting Effect of Religiosity on Environmental Concern among Political Conservatives in a Global Context." Social Problems (Online First): https://doi.org/10.1093/socpro/spaa066

Hekmatpour, Peyman, Thomas J. Burns, and Tom W. Boyd. 2017. "Is Islam pro-or antienvironmental? Interpretations and implications." Journal of Asian Research 1(1): 92-110.

Hekmatpour, Peyman, and Thomas J. Burns. 2019. 'Perception of Western governments' hostility to Islam among European Muslims before and after ISIS: The important roles of residential segregation and education." British Journal of Sociology 70(5): 2133-2165.

Ignazi, Piero. 1992. "The silent counter-revolution: Hypotheses on the emergence of extreme right-wing parties in Europe." European Journal of Political Research 22(1): 3-34.

Inglehart, Ronald. 1997. Modernization and Postmodernization: Cultural, Economic, and Political Change in 43 Societies. Princeton: Princeton University Press. 
Inglehart, Ronald, and Wayne E. Baker. 2000. "Modernization, cultural change, and the persistence of traditional values." American sociological review 65(1): 19-51.

Inglehart, Ronald and Pippa Norris. 2003. Rising Tide: Gender Equality and Cultural Change around the World. Cambridge: Cambridge University Press.

Inglehart, R., C. Haerpfer, A. Moreno, C. Welzel, K. Kizilova, J. Diez-Medrano, M. Lagos, P. Norris, E. Ponarin and B. Puranen et al. (eds.). 2014. World Values Survey: All Rounds-Country-Pooled Datafile Version. Madrid: JD Systems Institute.

Jayachandran, Seema. 2015. "The roots of gender inequality in developing countries." economics 7(1): 63-88.

Jordan, Jason. 2016. "Religion and inequality: the lasting impact of religious traditions and institutions on welfare state development." European Political Science Review 8(1): 25-48.

Juhn, Chinhui, Gergely Ujhelyi, and Carolina Villegas-Sanchez. 2014. "Men, women, and machines: How trade impacts gender inequality." Journal of Development Economics 106: 179-193.

Kane, Gillian. 2008. “Abortion Law Reform in Latin America: Lessons for Advocacy.” Gender and Development 16(2): 361-375.

Kelly, James III, Glenn S. Johnson, Tayler J. Mathews, Lolilta D. Gray, and Luisa E. Bowman. 2017. "Criminalizing Abortion During President Obama's Administration: An Exploratory Study." Race, Gender \& Class 24(3/4): 73-99.

Klasen, Stephan. 2002. "Low schooling for girls, slower growth for all? Cross-country evidence on the effect of gender inequality in education on economic development." The World Bank Economic Review 16(3): 345-373.

Knight, Carly R., and Mary C. Brinton. 2017. "One egalitarianism or several? Two decades of genderrole attitude change in Europe.” American Journal of Sociology 122(5): 1485-1532.

Knowles, Stephen, Paula K. Lorgelly, and P. Dorian Owen. 2002. "Are educational gender gaps a brake on economic development? Some cross-country empirical evidence." Oxford economic papers 54(1): 118-149.

Latt, Su Mon, Allison Milner, and Anne Kavanagh. 2019. "Abortion laws reform may reduce maternal mortality: an ecological study in 162 countries.” BMC women's health 19(1): 1-9.

Lange, Sarah L. de., Matthijs Rooduijn, and Tjitske Akkerman. 2016. Radical Right-Wing Populist Parties in Western Europe: into the Mainstream?. London: Routledge Taylor and Francis Group.

Marx, Karl. 1977 [1867]. Capital: a Critique of Political Economy. London: Lawrence and Wishart.

Millar, Erica. 2016. "Mourned Choices and Grievable Lives: The Anti-Abortion Movement's Influence in Defining the Abortion Experience in Australia Since the 1960s." Gender \& History 28(2): 501-519.

Ngai, L. Rachel, and Barbara Petrongolo. 2017. "Gender gaps and the rise of the service economy." American Economic Journal: Macroeconomics 9(4): 1-44.

Nicolaisen, Heidi, Hanne Cecilie Kavli, and Ragnhild Steen Jensen. 2019. Dualisation of Part-Time Work: the Development of Labour Market Insiders and Outsiders. Bristol, UK: Policy Press.

Norris, Pippa, and Ronald Inglehart. 2004. Sacred and Secular: Religion and Politics Worldwide. New York: Cambridge University Press.

Ogburn, William. 1961 [1932]. "The hypothesis of cultural lag”. In Parsons, Talcott., Edward Shils, Kaspar D. Naegele and Jesse R. Pitts. (eds.), Theories of Society: foundations of modern sociological theory. New York: Free Press.

Okonofua, Friday E. 2008. "Contribution of anti-abortion laws to maternal mortality in developing countries." Expert Review of Obstetrics \& Gynecology 3(2): 147-149.

Oesch, Daniel. 2008. "Explaining workers' support for right-wing populist parties in Western Europe: Evidence from Austria, Belgium, France, Norway, and Switzerland.” International Political Science Review 29(3): 349-373. 
Pascall, Gillian and Sirin Sung. 2007. "Gender and East Asian Welfare States: from Confucianism to Gender Equality." Fourth Annual East Asian Social Policy Research Network (EASP), 20-21 October 2007, Tokyo.

Permanyer, Iñaki. 2013. "A critical assessment of the UNDP's gender inequality index." Feminist Economics 19(2): 1-32.

Psacharopoulos, George, and Zafiris Tzannatos. 1989. "Female labor force participation: An international perspective." The World Bank Research Observer 4(2): 187-201.

Rosenfeld, Rachel A., and Arne L. Kalleberg. 1991. "Gender inequality in the labor market: A crossnational perspective.” Acta Sociologica 34(3): 207-225.

Rossi, Pauline, and Léa Rouanet. 2015. "Gender preferences in Africa: A comparative analysis of fertility choices." World Development 72: 326-345.

Rydgren, Jens. 2005. Movements of Exclusion: Radical Right-Wing Populism in the Western World. New York: Nova Science.

Scarborough, William J., Ray Sin, and Barbara Risman. 2019. "Attitudes and the stalled gender revolution: Egalitarianism, traditionalism, and ambivalence from 1977 through 2016." Gender \& Society 33(2): 173-200.

Schnabel, Landon. 2016a. "Religion and gender equality worldwide: A country-level analysis." Social Indicators Research 129(2): 893-907.

Schnabel, Landon. 2016b. "Gender and homosexuality attitudes across religious groups from the 1970s to 2014: Similarity, distinction, and adaptation.” Social Science Research 55: 31-47.

Seguino, Stephanie. 2011. "Help or hindrance? Religion's impact on gender inequality in attitudes and outcomes." World Development 39(8): 1308-1321.

Semyonov, Moshe. 1980. “The Social Context of Women's Labor Force Participation: A Comparative Analysis." American Journal of Sociology 86(3): 534-550.

Semyonov, Moshe. 2018. "Development and Gender-Linked Economic Inequality in the Era of Globalization." Sociology of Development 4(3): 304-324.

Sen, Gita. 2007. "Informal institutions and gender equality.” In J. Jutting, D. Drechsler, S. Bartsch, and I. de Soysa (Eds.), Informal institutions: How social norms help or hinder development. Paris, France: OECD.

Shaw, Dorothy, and Wendy V. Norman. 2018. "A tale of two countries: women's reproductive rights in Ireland and the US." BMJ 361 :k2471.

Shelton, Beth Anne, and Daphne John. 1996. "The division of household labor." Annual review of sociology 22(1): 299-322.

Singh, K., and S. S. Ratnam. 1998. "The influence of abortion legislation on maternal mortality." International Journal of Gynecology \& Obstetrics 63:123-129.

Tranby, Eric, and Samantha E. Zulkowski. 2012. "Religion as cultural power: The role of religion in influencing Americans' symbolic boundaries around gender and sexuality." Sociology Compass 6(11): 870-882.

VanHeuvelen, Tom. 2014. "The religious context of welfare attitudes.” Journal for the Scientific Study of Religion 53(2): 268-295.

Wallace, Anthony F.C. 1966. Religion: An Anthropological View. New York: Random House.

Weber, Max. 1985 [1904]. The protestant ethic and the spirit of capitalism. London: Unwin.

World Economic Forum 2017. Global Gender Gap Report 2017. Geneva: World Economic Forum. Available at: http://reports.weforum.org/global-gender-gap-report-2017

Wright, Erik Olin, Janeen Baxter, and Gunn Elisabeth Birkelund. 1995. "The gender gap in workplace authority: A cross-national study." American sociological review 60(3): 407-435. 
Yu, Chong Ho, Danielle Reimer, Anna Lee, Jean-Paul Snijder, and Hyun Seo Lee. 2017. “A Triangulated and Exploratory Study of the Relationships Between Secularization, Religiosity, and Social Wellbeing." Social Indicators Research 131(3): 1103-1119. 
TABLE 1. WELZEL'S SECULAR VALUES SUB-INDICES

\begin{tabular}{|c|c|c|}
\hline Sub-Indices & Item(s) in the Survey & Measurement \\
\hline Defiance & $\begin{array}{l}\text { One of my main goals in life has been to make my } \\
\text { parents proud } \\
\text { Is it good or bad to have a greater respect for authority? } \\
\text { How proud you are to be [Respondents Nationality: } \\
\text { e.g., an American] }\end{array}$ & $\begin{array}{l}\text { 4-point Likert scale: "Strongly Agree" to } \\
\text { "Strongly Disagree" "} \\
\text { Binary: "Good" vs. "Bad" } \\
\text { 4-point Likert scale: "Very proud" to } \\
\text { "Not at all proud" }\end{array}$ \\
\hline Disbelief & $\begin{array}{l}\text { How important is religion in your everyday life } \\
\text { Are you a religious person } \\
\text { How often do you attend religious services }\end{array}$ & $\begin{array}{l}\text { 4-point Likert scale: "Very proud" to } \\
\text { "Not at all proud" } \\
\text { Binary: "Yes" vs. "No" } \\
\text { 7-point Likert scale: "More than once a } \\
\text { week" to "Never" }\end{array}$ \\
\hline Relativism & $\begin{array}{l}\text { Do you believe that "Avoiding a fare on public } \\
\text { transport" can ever be justified? } \\
\text { Do you believe that "Cheating on taxes if you have a } \\
\text { chance" can ever be justified? } \\
\text { Do you believe that "accepting a bribe" can ever be } \\
\text { justified? }\end{array}$ & $\begin{array}{l}\text { 10-point Liker scale: "Never justifiable" } \\
\text { to "Always justifiable" }\end{array}$ \\
\hline Skepticism & $\begin{array}{l}\text { How much confidence you have in the armed forces } \\
\text { How much confidence you have in the police } \\
\text { How much confidence you have in the courts }\end{array}$ & $\begin{array}{l}\text { 4-point Likert scale: "A great deal" to } \\
\text { "None at all" }\end{array}$ \\
\hline
\end{tabular}

Data sources: World Values Survey (1991 - 2013) 


\begin{tabular}{|c|c|c|c|}
\hline Variables & Description & $\begin{array}{l}\text { Mean or } \\
\quad \%\end{array}$ & S.D. \\
\hline Maternal Mortality & $\begin{array}{l}\text { Number of deaths per 100,000 live births } \\
\quad \text { Min }=3, \operatorname{Max}=813\end{array}$ & 89.87 & 141.67 \\
\hline Adolescent Pregnancy & $\begin{array}{l}\text { Number of births per 1,000 women ages } 15-19 \\
\quad \operatorname{Min}=1.86, \operatorname{Max}=185.47\end{array}$ & 42.68 & 35.01 \\
\hline Labor Force Participation & $\begin{array}{l}\text { Percent share of women active in labor force } \\
\qquad \text { Min }=12.56, \operatorname{Max}=86.42\end{array}$ & 56.08 & 16.88 \\
\hline Parliamentary Representation & $\begin{array}{l}\text { Percent proportion of seats held by women in national } \\
\text { parliaments } \\
\quad \operatorname{Min}=0, \operatorname{Max}=56.3\end{array}$ & 18.09 & 11.35 \\
\hline Secondary Education & $\begin{array}{l}\text { Percent share of women with completed secondary education } \\
\quad \operatorname{Min}=3.5, \operatorname{Max}=90.36\end{array}$ & 43.21 & 21.89 \\
\hline Attitude 1 & $\begin{array}{l}\text { Percent share of the population who believe that "men should } \\
\text { have more right to a job than women." } \\
\quad \text { Min }=2.06, \operatorname{Max}=89.61\end{array}$ & 34.33 & 19.01 \\
\hline Attitude 2 & $\begin{array}{l}\text { Percent share of the population who believe that " men make } \\
\text { better political leaders than women do" } \\
\text { Min }=1.45, \operatorname{Max}=80.00\end{array}$ & 16.36 & 13.61 \\
\hline Attitude 3 & $\begin{array}{l}\text { Percent share of the population who believe that " university } \\
\text { is more important for a boy than for a girl." } \\
\text { Min }=0, \operatorname{Max}=41.75\end{array}$ & 7.82 & 6.69 \\
\hline Secular Values & $\begin{array}{l}\text { Average of Welzel's Secular Values for the male population } \\
\quad \text { Min }=0.14, \operatorname{Max}=0.53\end{array}$ & 0.36 & 0.09 \\
\hline Log(GDP per capita) & $\begin{array}{l}\text { Real gross domestic product at chained purchasing power } \\
\text { parity (PPP) rates adjusted for } 2011 \text { United States dollars } \\
\text { Min }=0.03, \operatorname{Max}=4.06\end{array}$ & 2.43 & 1.01 \\
\hline Log(Trade Openness) & $\begin{array}{l}\text { Trade as a share of GDP per capita, Logged } \\
\quad \operatorname{Min}=2.62, \operatorname{Max}=5.31\end{array}$ & 4.10 & 0.50 \\
\hline Service Sector & $\begin{array}{l}\text { Percentage share of the active labor force in the service sector } \\
\quad \operatorname{Min}=12.43, \operatorname{Max}=80.06\end{array}$ & 54.68 & 16.72 \\
\hline Democracy & $\begin{array}{l}\text { Polity IV democracy index } \\
\qquad \operatorname{Min}=-10, \operatorname{Max}=10\end{array}$ & 6.29 & 5.15 \\
\hline \multicolumn{4}{|l|}{ Geographical Region } \\
\hline Eastern Europe & & $18 \%$ & - \\
\hline Middle East & & $15 \%$ & - \\
\hline South America & & $19 \%$ & - \\
\hline East Asia & & $17 \%$ & - \\
\hline Sub-Saharan Africa & & $9 \%$ & - \\
\hline Western Europe and North & erica & $22 \%$ & - \\
\hline
\end{tabular}

Data sources: World Values Survey (1991 - 2013), Penn World Table 9.0 - 2015; Polity IV Project - 2015; World Development Indicators (the World Bank) 
TABLE 3. HYBRID MODELS OF GENDER INEQUALITY INDICATORS

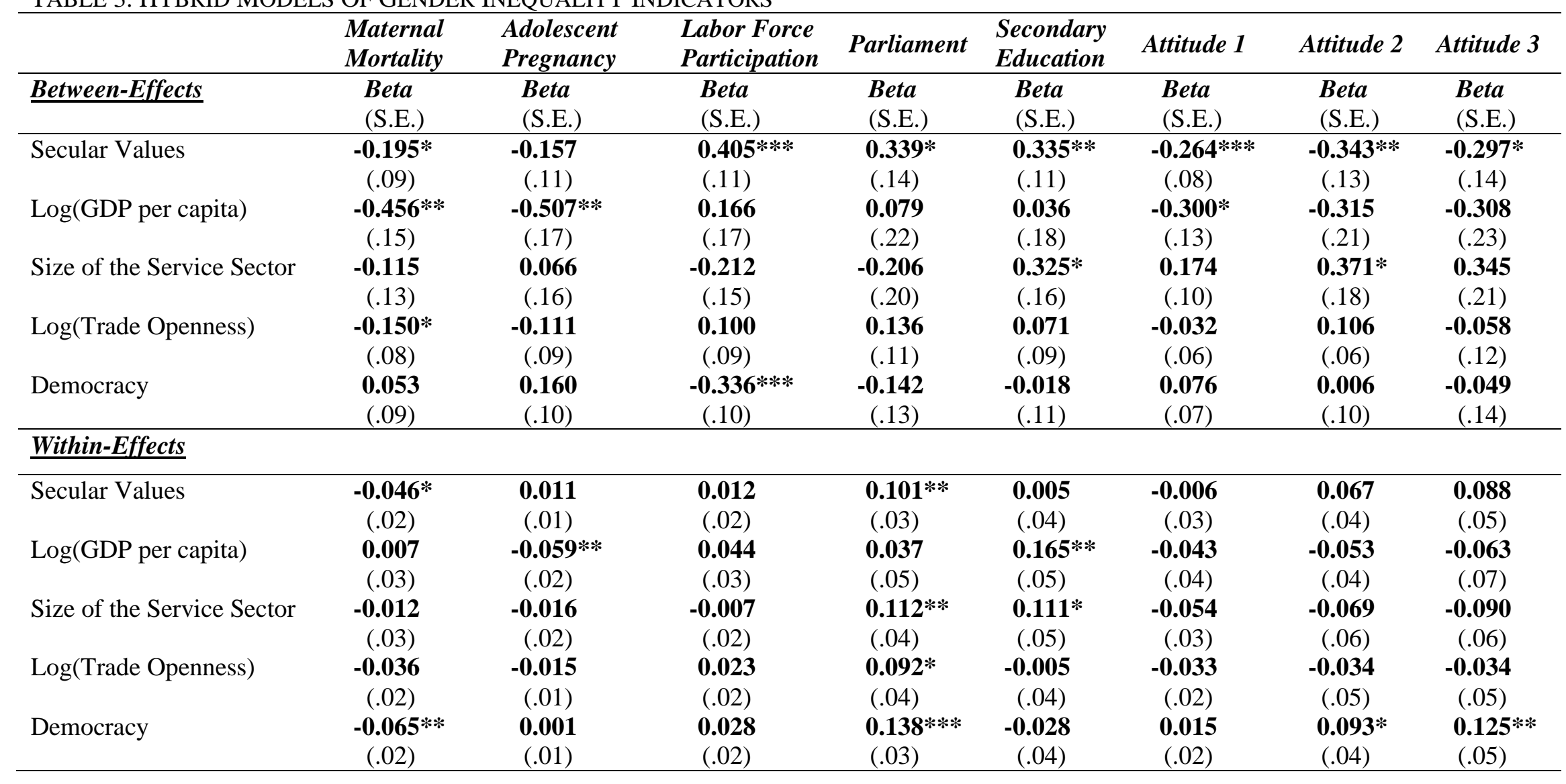


TABLE 3. HYBRID MODELS OF GENDER INEQUALITY INDICATORS (Continued)

\begin{tabular}{|c|c|c|c|c|c|c|c|c|}
\hline & $\begin{array}{l}\text { Maternal } \\
\text { Mortality }\end{array}$ & $\begin{array}{l}\text { Adolescent } \\
\text { Pregnancy }\end{array}$ & $\begin{array}{l}\text { Labor Force } \\
\text { Participation }\end{array}$ & Parliament & $\begin{array}{l}\text { Secondary } \\
\text { Education }\end{array}$ & Attitude 1 & Attitude 2 & Attitude 3 \\
\hline \multicolumn{9}{|l|}{ Time Invariant Variables } \\
\hline \multicolumn{9}{|l|}{ Geographic Region $^{a}$} \\
\hline Eastern Europe & $\begin{array}{c}\mathbf{- 0 . 3 3 6} \\
(.25)\end{array}$ & $\begin{array}{c}\mathbf{- 0 . 0 0 6} \\
(.29)\end{array}$ & $\begin{array}{c}\mathbf{- 0 . 7 5 8 * *} \\
(.28)\end{array}$ & $\begin{array}{l}-\mathbf{1 . 5 1 4} * * * \\
(.36)\end{array}$ & $\begin{array}{c}\mathbf{0 . 4 8 5} \\
(.30)\end{array}$ & $\begin{array}{l}\mathbf{0 . 9 2 8} * * * \\
(.19)\end{array}$ & $\begin{array}{l}\mathbf{1 . 1 8 3} * * * \\
(.28)\end{array}$ & $\begin{array}{l}\text { 1.096** } \\
(.38)\end{array}$ \\
\hline Middle East & $\begin{array}{r}\mathbf{- 0 . 5 2 9} \\
(.31)\end{array}$ & $\begin{array}{c}\mathbf{0 . 0 3 3} \\
(.37)\end{array}$ & $\begin{array}{c}\mathbf{- 2 . 3 6 1 * * *} \\
(.36)\end{array}$ & $\begin{array}{c}\mathbf{- 1 . 2 7 1} * * \\
(.46)\end{array}$ & $\begin{array}{c}\mathbf{0 . 0 4 0} \\
(.38)\end{array}$ & $\begin{array}{l}\mathbf{2 . 1 3 3}^{* * *} \\
(.24)\end{array}$ & $\begin{array}{l}1.995 * * * \\
(.34)\end{array}$ & $\begin{array}{l}1.482 * * \\
(.48)\end{array}$ \\
\hline South America & $\begin{array}{c}\mathbf{- 0 . 4 1 6} \\
(.26)\end{array}$ & $\begin{array}{l}\text { 1.111**** } \\
(.31)\end{array}$ & $\begin{array}{c}\mathbf{- 0 . 6 8 2 *} \\
(.30)\end{array}$ & $\begin{array}{r}-\mathbf{- 0 . 6 6 1} \\
(.38)\end{array}$ & $\begin{array}{c}\mathbf{- 0 . 6 5 6 *} \\
(.31)\end{array}$ & $\begin{array}{r}\mathbf{- 0 . 0 4 7} \\
(.17)\end{array}$ & $\begin{array}{l}\mathbf{0 . 1 3 2} \\
(.20)\end{array}$ & $\begin{array}{l}\mathbf{0 . 2 3 8} \\
(.40)\end{array}$ \\
\hline East Asia & $\begin{array}{c}\mathbf{- 0 . 1 9 7} \\
(.28)\end{array}$ & $\begin{array}{c}\mathbf{0 . 0 1 5} \\
(.34)\end{array}$ & $\begin{array}{c}-\mathbf{0 . 9 6 2} * * \\
(.33)\end{array}$ & $\begin{array}{c}-\mathbf{1 . 3 0 2} * * \\
(.41)\end{array}$ & $\begin{array}{c}\mathbf{- 0 . 0 3 2} \\
(.34)\end{array}$ & $\begin{array}{l}1.324 * * * \\
(.20)\end{array}$ & $\begin{array}{l}\mathbf{0 . 7 2 7} * * * \\
(.20)\end{array}$ & $\begin{array}{l}\mathbf{0 . 8 8 5}^{*} \\
(.43)\end{array}$ \\
\hline Sub-Saharan Africa & $\begin{array}{l}\text { 1.321**** } \\
(.37)\end{array}$ & $\begin{array}{l}\text { 1.522**** } \\
(.44)\end{array}$ & $\begin{array}{c}\mathbf{0 . 3 3 6} \\
(.43)\end{array}$ & $\begin{array}{c}-\mathbf{- 0 . 2 3 6} \\
(.54)\end{array}$ & $\begin{array}{r}\mathbf{- 0 . 1 9 6} \\
(.44)\end{array}$ & $\begin{array}{l}\mathbf{0 . 5 4 3} * \\
(.25)\end{array}$ & $\begin{array}{l}\text { 1.002*** } \\
(.37)\end{array}$ & $\begin{array}{c}\mathbf{0 . 6 7 9} \\
(.56)\end{array}$ \\
\hline Intercept & $\begin{array}{c}\mathbf{0 . 1 7 9} \\
(.18) \\
\end{array}$ & $\begin{array}{c}\mathbf{- 0 . 2 8 8} \\
(.22)\end{array}$ & $\begin{array}{l}\mathbf{0 . 7 2 5} * * * \\
(.21)\end{array}$ & $\begin{array}{l}\mathbf{0 . 7 7 2} * * \\
(.27)\end{array}$ & $\begin{array}{c}\mathbf{0 . 0 2 8} \\
(.22) \\
\end{array}$ & $\begin{array}{c}\mathbf{- 0 . 7 4 5} * * * \\
(.13)\end{array}$ & $\begin{array}{c}\mathbf{- 0 . 7 2 4} * * * \\
(.14)\end{array}$ & $\begin{array}{c}-\mathbf{- 0 . 6 4 6 *} \\
(.28) \\
\end{array}$ \\
\hline Number of Observations & 150 & 150 & 150 & 150 & 150 & 150 & 150 & 150 \\
\hline Number of Countries & 70 & 70 & 70 & 70 & 70 & 70 & 70 & 70 \\
\hline Between $R^{2}$ & 0.83 & 0.76 & 0.73 & 0.41 & 0.64 & 0.85 & 0.76 & 0.50 \\
\hline Within $R^{2}$ & 0.25 & 0.35 & 0.12 & 0.57 & 0.41 & 0.24 & 0.19 & 0.17 \\
\hline Overall $R^{2}$ & 0.77 & 0.75 & 0.68 & 0.51 & 0.58 & 0.83 & 0.69 & 0.46 \\
\hline
\end{tabular}

NOTE. $-(* p<0.05, \quad * * p<0.01, \quad * * * p<0.001)$, Robust standard errors in parentheses.

Data sources: World Value Survey longitudinal dataset (1991 - 2013) - 2016; Penn World Table 9.0 - 2015; Polity IV Project - 2015; World Development Indicators (the World Bank)

${ }^{\text {a }}$ Reference group: Western Europe and North America 
TABLE 4. FIXED-EFFECTS MODELS OF SELECTED GENDER INEQUALITY INDICATORS

\begin{tabular}{|c|c|c|c|c|}
\hline \multirow[b]{2}{*}{ Independent Variables } & \multicolumn{2}{|c|}{ Maternal Mortality } & \multicolumn{2}{|c|}{ Parliament } \\
\hline & $\begin{array}{c}\text { Model 1 } \\
\text { Coeff. (S.E.) }\end{array}$ & $\begin{array}{c}\text { Model } 2 \\
\text { Coeff. (S.E.) }\end{array}$ & $\begin{array}{c}\text { Model 3 } \\
\text { Coeff. (S.E.) }\end{array}$ & $\begin{array}{c}\text { Model } 4 \\
\text { Coeff. (S.E.) }\end{array}$ \\
\hline \multicolumn{5}{|l|}{ Main Effects } \\
\hline \multirow[t]{2}{*}{ Secular Values } & $-0.154 *$ & -0.092 & $0.334 * *$ & $0.316 * *$ \\
\hline & $(.06)$ & $(.06)$ & $(.11)$ & $(.11)$ \\
\hline \multirow[t]{2}{*}{ Log(GDP per capita) } & 0.036 & 0.029 & 0.182 & 0.184 \\
\hline & $(.14)$ & $(.13)$ & $(.24)$ & $(.24)$ \\
\hline \multicolumn{5}{|l|}{ Interaction Effect } \\
\hline $\log ($ GDP per capita $) \times$ & & $0.252 * * *$ & & $-0.074^{\dagger}$ \\
\hline Secular Values & & $(.06)$ & & $(.11)$ \\
\hline \multicolumn{5}{|l|}{ Control Variables } \\
\hline \multirow[t]{2}{*}{ Service Sector (\%Labor Force) } & -0.065 & -0.110 & $0.603 *$ & $0.617 * *$ \\
\hline & $(.14)$ & $(.13)$ & $(.23)$ & $(.23)$ \\
\hline \multirow[t]{2}{*}{ Log(Trade Openness) } & -0.120 & -0.083 & $0.309 *$ & $0.299 *$ \\
\hline & $(.07)$ & $(.07)$ & $(.12)$ & $(.12)$ \\
\hline \multirow[t]{2}{*}{ Democracy } & $-0.211 * *$ & $-0.204 * * *$ & $0.450 * * *$ & $0.448 * * *$ \\
\hline & $(.07)$ & $(.06)$ & $(.11)$ & $(.11)$ \\
\hline Number of Observations & 150 & 150 & 150 & 150 \\
\hline Number of Countries & 70 & 70 & 70 & 70 \\
\hline Between $R^{2}$ & 0.30 & 0.58 & 0.05 & 0.06 \\
\hline Within $R^{2}$ & 0.25 & 0.40 & 0.57 & 0.58 \\
\hline Overall $R^{2}$ & 0.30 & 0.55 & 0.11 & 0.12 \\
\hline
\end{tabular}

NOTE. - $(\dagger p<0.1 * p<0.05, * * p<0.01, * * * p<0.001)$, Robust standard errors in parentheses.

Data sources: World Value Survey longitudinal dataset (1991 - 2013), Penn World Table 9.0 - 2015; Polity IV Project 2015; World Development Indicators (the World Bank)

${ }^{\text {a }}$ Reference group: Western Europe and North America 
Figure 1. Scatter Plots of Gender Inequality Indicators by Secular Values
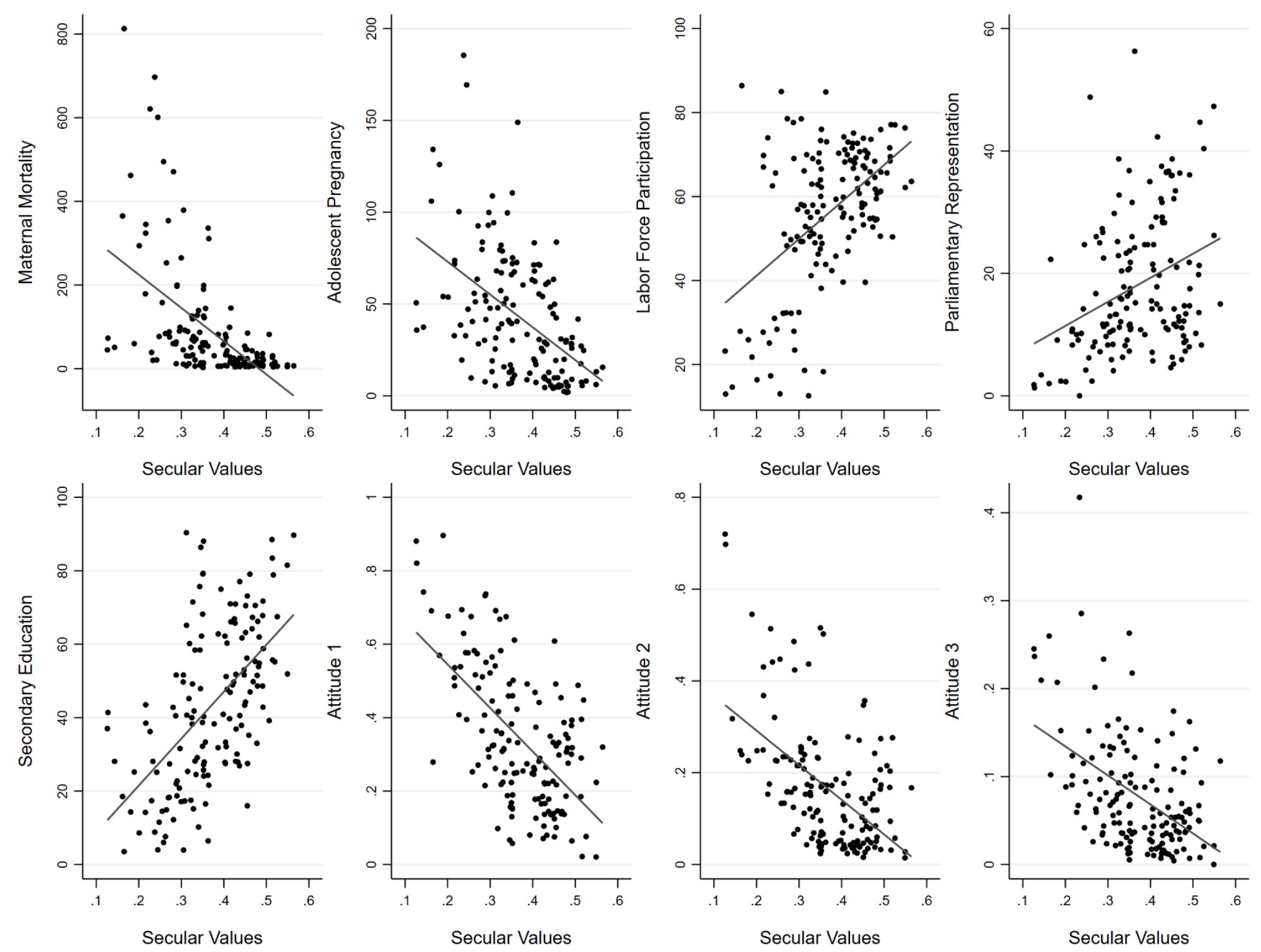

Data Sources: World Value Survey longitudinal dataset (1991 - 2013) , Penn World Table 9.0 - 2015; Polity IV Project - 2015; World Development Indicators (the World Bank) 
Figure 2. Predicted Change in Maternal Mortality Rates (S.D.) by Secularization Across Countries' Income

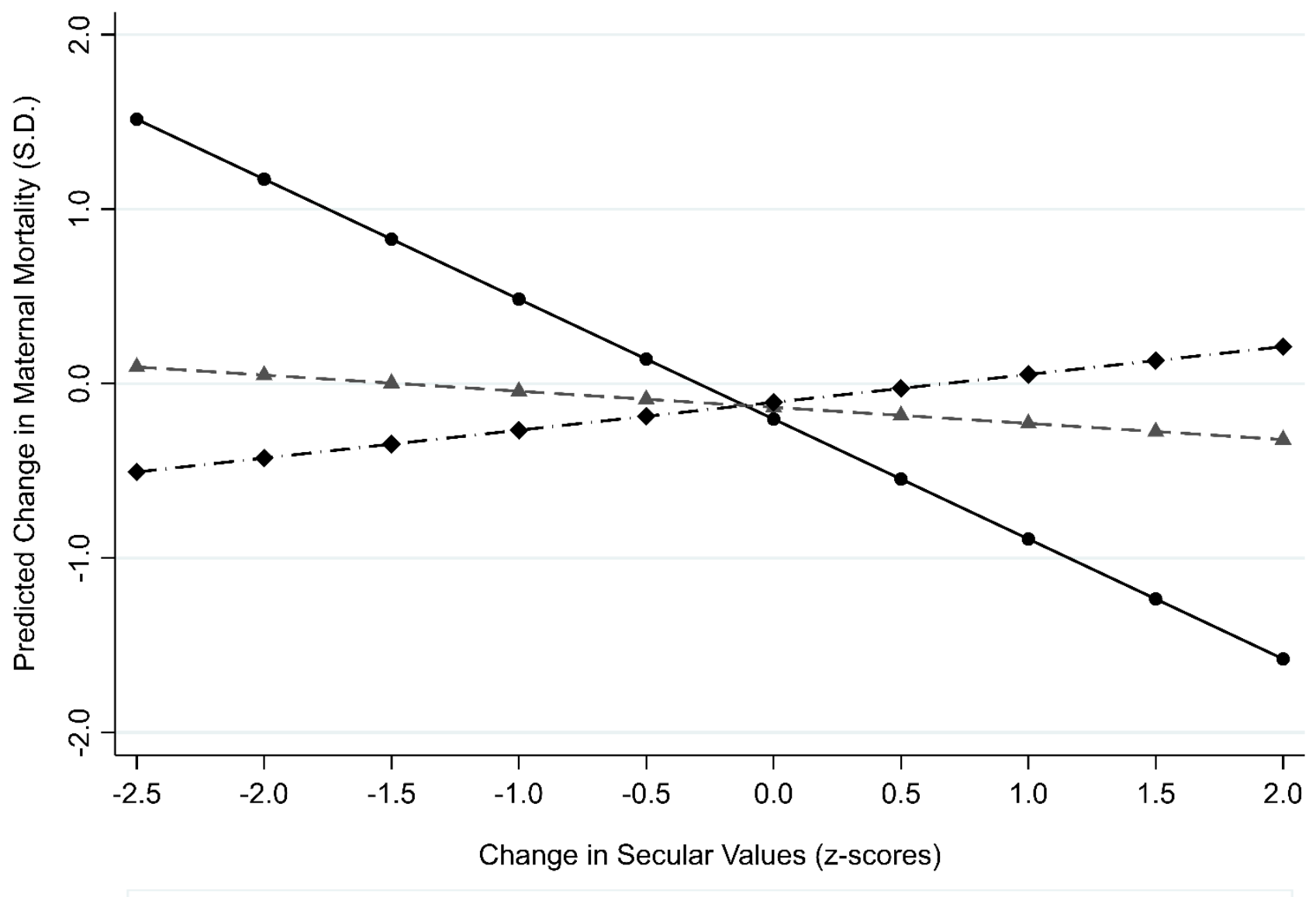

$\longrightarrow \rightarrow-\cdots$ High-Income Countries $\quad-\quad-\quad-$ Middle-Income Countries $\longrightarrow$ Low-Income Countries

$\mathrm{N}=150$ (country-year)

Data Sources: World Value Survey longitudinal dataset (1991 - 2013), Penn World Table 9.0 - 2015; World Development Indicators (the World Bank) 


\section{Figure 3. Predicted Change in Female Parliamentary Representation (S.D.) by Secularization Across Countries' Income}

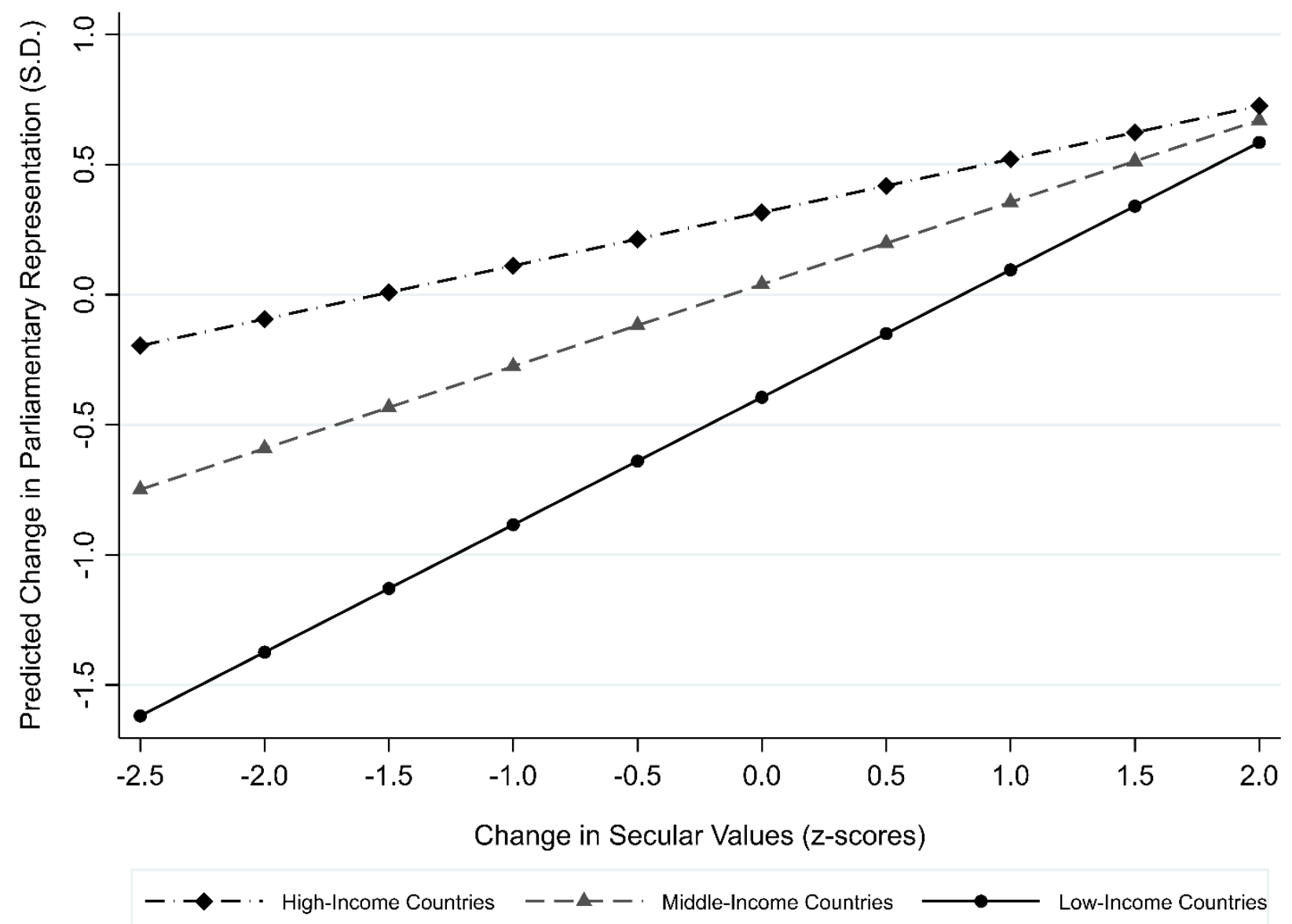

$\mathrm{N}=150$ (country-year)

Data Sources: World Value Survey longitudinal dataset (1991 - 2013), Penn World Table 9.0 - 2015; World Development Indicators (the World Bank) 